Asian J. Med. Biol. Res. 2020, 6 (1), 99-106; doi: 10.3329/ajmbr.v6i1.46484

\author{
Asian Journal of \\ Medical and Biological Research \\ ISSN 2411-4472 (Print) 2412-5571 (Online) \\ www.ebupress.com/journal/ajmbr
}

\title{
Article \\ Survey on beef cattle production system in Saylem Woreda, south west Ethiopia
}

\begin{abstract}
Solomon Addisu*
Jimma University College of Agriculture and Veterinary Medicine, School of Veterinary Medicine, P. O. Box= 307, Ethiopia

${ }^{*}$ Corresponding author: Solomon Addisu, Jimma University College of Agriculture and Veterinary Medicine, School of Veterinary Medicine, P. O. Box= 307, Ethiopia. Phone: +251917013104; E-mail: soladdisu04@gmail.com
\end{abstract}

Received: 27 February 2020/Accepted: 23 March 2020/ Published: 31 March 2020

\begin{abstract}
In Ethiopia livestock production is an integral part of the Ethiopian agricultural system. Beef cattle production plays an important role in the economies and livelihoods of farmers and pastoralists. Saylem Woreda is one of the remote setting in Ethiopia were information about beef production system is not well studied. Hence, this study was conducted to assess beef cattle production system; marketing and avalable feed resources utilized by beef cattle producers and the factors affecing beef cattle production of the study area through questionaire survey in Saylem woreda, south west Ethiopia. A total of 80 households were interviewed about $78.8 \%\left(\mathrm{X}^{2}=26.45 ; \mathrm{p}=0.000\right)$ of respondents practiced beef cattle production was statistically significant. $93.8 \%$ $\left(\mathrm{X}^{2}=61.25 ; \mathrm{p}=0.002\right)$ of the respondents use only grazing of field grass for beef cattle production. Beef cattle marketing in the study area function at primary markets $78.8 \%\left(X^{2}=2.645 ; p=0.963\right)$ of respondents had access to market information before sale was not statistically significant. Most of the respondents $81.2 \%\left(\mathrm{X}^{2}=19.00\right.$; $\mathrm{p}=0.003$ ) determined factors for price of beef cattle were color, age, weight and agreement of sellers and buyers was statistically significant. The main constraints complained by the respondents in the study area $96.2 \%$ had lack of road (transportation) to get market access; 92.5\% had prevalence of beef cattle disease in the area and $31.8 \%$ had shortage of feed and water and lack of genetically improved beef for fattening. Beef cattle production and marketing systems in Saylem woreda have many levels of formal and informal traders. Therefore, administrative bodies concerned these issues should give priority to find solution for these problems facing beef cattle producing farmers in the study area.
\end{abstract}

Keywords: beef cattle; marketing system; production; Saylem Woreda; respondents

\section{Background}

Ethiopia, like most of the countries in sub-Saharan Africans heavily dependent on agriculture. The agriculture sector plays an important role in the national economy and it is the source of income and employment for the rural population (Nigusse, 2001). The agricultural sector in Ethiopia, engaging 85\% of the population, contributes 52\% to the gross domestic product (GDP) and 90\% to the foreign exchange earnings (CSA, 2014). Livestock production is an integral part of the Ethiopian agricultural system. The subsector contributes 12 and $33 \%$ to the total Gross Domestic Product (GDP) and agricultural Gross Domestic Product (GDP), respectively, and provides livelihood for 65\% of the population (LMA, 2001). Beef cattle production plays an important role in the economies and livelihoods of farmers and pastoralists (CSA, 2014). Livestock systems represent a potential pathway out of poverty for many smallholders in the developing world. The majority of the world's rural poor, and a significant proportion of the urban poor, keep livestock and use them in a variety of ways that extend far beyond income generation. In many cases, livestock are a central component of smallholder risk management strategies (Bailey et al., 1999). The economic contribution of the livestock sub-sector in Ethiopia is also about $12 \%$ of the total and $33 \%$ of agricultural Gross Domestic Product (GDP) and provides livelihood for 
$65 \%$ of the population. Livestock in Ethiopia provide draught power, income to farming communities, means of investment and important source of foreign exchange earning to the nation (Solomon et al., 2003).

The beef cattle production systems are predominantly categorized as agro-pastoral system in the lowlands, and the mixed crop-livestock system in the highlands. Traditionally, fattening of animals in both systems concentrates on male animals and on females which are either infertile or have finished their reproductive cycle. In the lowland agro-pastoral system, grazing is the most common source of feed, with limited use of crop residues, whereas in the highland system, crop residues are the most important source of animal feed. During the wet season, when crop residues are scarce in the highlands, male animals are taken to the lowland areas for grazing (Elias et al., 2007). Beef cattle production ranges from the beef cow herds that typically graze on pastureland or graze the remaining residue on the land after grain harvest to growing and finishing young cattle in feedlots. The feedlot-housing systems used in beef cattle production typically varies by climate and can range from open earthen lots with very little shelter to open shed and lot or an enclosed confinement building. Manure handling and storage ranges from solid manure with bedding included, and runoff water from open lots to liquid slurry and treatment lagoon systems. Due to the increasing size of beef operations, the large volume of manure production, collection, storage and application to the land has presented challenges (Daniel, 2008).

In different parts of Ethiopia there was some survey works done to assess beef cattle production and marketing systems. But no works was done in Saylem woreda, south west Ethiopia. Therefore, this study was focused to :

$>$ To assess beef cattle production system, marketing and avalable feed resources utilized by beef cattle producers in the study area through questionaire survey.

$>$ To assess the constraints of the beef cattle production system of the study area through questionaire survey.

\section{Materials and Methods}

\subsection{Description of the study area}

The study was conducted from September, 2017 to June, 2018 in Saylem woreda of South Nation Nationalities Peoples Regional State, South West Ethiopia. Saylem Woreda is far $600 \mathrm{kms}$ from Addis Ababa and located with a longitude $35^{\circ} 0^{\prime} 2^{\prime \prime}$ to $35^{0} 0^{\prime} 5^{\prime \prime}$ West and latitude $7^{0} 2^{\prime} 1^{\prime \prime}$ to $7^{0} 4^{\prime} 9^{\prime \prime}$ North and an altitude of 1800 to 2200 meters above sea level. Saylem woreda has received an average annual rainfall ranging from $3212.3 \mathrm{~mm}$ to $4159 \mathrm{~mm}$ and an average annual temperature ranging from $11.96^{\circ} \mathrm{c}$ to $21.9^{\circ} \mathrm{c}$. The agro ecological zone is high land and the major economic activities of the population were depends on farming crops and livestock production. Saylem woreda is one of the highly potential areas in livestock resources, but a lot of constraints are wide spread for the reduction of animal's production systems in the area (Saylem Woreda Livestock and Fishery Development Office, 2018).

\subsection{Study design and sampling technique}

A questionnaire survey was conducted from September, 2017 to June, 2018 on 80 households to assess the beef cattle production system, marketing and avalable feed resources utilized by beef cattle producers and also the major constraints of the beef cattle production system in the study area. During the study time, four study kebeles (namely Techib, Dino, Senteria and Qoci kebeles) were selected purposively based on maximum; medium and minimum beef cattle production practice takes place. Within each kebeles; the households were selected for interview by using simple random sampling technique. Hence, 20 households were selected from each kebeles and totally 80 households were participated in this study.

\subsection{Methods of data collection}

\subsubsection{Questionnaire field survey on beef cattle producers}

Questionnaire field survey was a primary data which were obtained through administered predesigned questionnaire to households from each selected kebeles. The objective of the questionnaire survey was explained to the participants before start of the interview. Questionnaire surveys with open and closed questions were used amongst the households and who were willing to participate in the survey. The owners' or one from the member of the households were interviewed in their local language. The questionnaire was developed in English and translated into Kafigna language for participants. The questionnaire was basically divided in to five parts comprising: Background information of the respondents'; beef cattle production system practiced in the area; feeding and watering sources; marketing system and major constraints for beef cattle production in the study area. This questionnaire survey was conducted on simple randomly selected 80 households from four purposively selected kebeles (namely Techib, Dino, Senteria and Qoci kebeles). From these kebeles Techib 
kebele is the highest or maximum beef production was practiced, in Dino and Senteria kebeles were medium beef production were practiced and finally the lowest beef production was practiced in Qoci kebele.

\subsection{Data management and statistical analysis}

The samples were collected based up on the appropriate sample collection methodology accordingly with the time frame work. All the collected data was entered through Microsoft Excel 2007 program and data analysis was performed with Pearson Chi-square $\left(\mathrm{X}^{2}\right)$ using SPSS version 16 statistical computer software. A p-value less than 0.05 were considered statistically significant with $95 \%$ confidence interval. Also descriptive analysis was employed for data analysis.

\section{Results and Discussion}

\subsection{Demographic characteristic of the participants}

General demographic characteristic results of the households participated in interview are summarized in Table 1. On average, there were 20 household in each kebele were participated in the study area. Totally 80 households participated, $86.2 \%$ were males and $13.8 \%$ were females. Age distribution of the participants were classified in to three: young (15-30 years old); adult (30-60 years) and old (above 60 years old) in this study and the result showed young $17.5 \%$, adult $56.2 \%$ and old $26.2 \%$. Education level of the household heads were Illiterates $31.2 \%$; basic reading and writing $43.8 \%$, only $11.2 \%$ of them enrolled in primary schools, and only 13.8 were attended secondary school. In this study the proportion of illiterates $(31.2 \%)$ was less than reported by Daniel (2008) (70.7\%) in Borena zone. This difference may be due to shortage of the access school. Income sources of the household heads in the study area, both crop and livestock production are the main sources of income and are closely linked to the social and cultural lives of the community.

\subsection{Beef cattle production system}

Questionnaire results of beef cattle production system are shown in Table 2. Beef cattle production refers to the producer stayed in cattle production activity. From producers' survey, it was found out that most of the producers had been in cattle production activities for ling time. Results of this study revealed that $78.8 \%$ of the respondents indicated that they were involved in beef cattle production, but $21.2 \%$ were not involved beef cattle production. From the respondents, $47.5 \%$ were reared beef cattle to generate cash income; $10 \%$ for farming only and $42.5 \%$ for both to generate cash income and farming purposes. $61.2 \%$ of the participants got technical support on health, feed, marketing and beef cattle utilization from office of agriculture and $15 \%$ from fellow farmers, but $67.5 \%$ responds the technical support is not sufficient. $96.2 \%$ of the respondents follow traditional beef cattle production system.

\subsection{Feeding system of beef cattle production}

Questionnaire results on feeding system of beef cattle production are shown in Table 3. According to the response of $80 \%$ households, they had sufficient grazing land for their cattle, but $20 \%$ of the respondents explained that the grazing land for their cattle is not enough. Accordingly, the results of this study showed that 45\% households, there is feed shortage for their cattle in general and $17 \%$ households responded that the problem is there but it depends on the seasons, while the remaining $21 \%$ replied that there is no feed problem in their area. According by the study of Sintayehu et al. (2010) in the relatively wet highlands, available livestock feed (including grazing) is estimated to fall $40 \%$ short of requirement. Dry period or season is the most critical periods when feed shortage occurs and water resources decrease both in amount and quality, as indicated by the respondents. $96.2 \%$ of them do not store feed for their cattle, but only $3.8 \%$ of the respondents reported that they just store feed to the home for their cattle to use during dry season.

From the respondents, $93.8 \%$ were used field grazing system on natural pasture which is the most common practice for all species of animals in the Saylem woreda. Some of them used salt as a supplement. Those ready for sale are supplemented with salt as the producers strongly believe in that salt is helpful for conditioning their beef cattle before sale. Bruk and Tafesse (2000) obtained a comparable result that in pastoral areas, the natural pasture is the main source of feed for livestock and in order to utilize the resource properly. Only $6.2 \%$ were used some of the farm products and residues used as a source of feed to the different groups of cattle. Water resources in the study area are dominated by the rivers. Among the 80 respondents $52.5 \%$ of them indicated that there are problems with the water resources such as poor water quality, thus the rest reported that during the dry periods the water quality is poor and results in water borne diseases. 


\subsection{Beef cattle marketing system in Saylem Woreda}

Results of beef cattle marketing system of the study area are shown in Table 4. Markets are an area where animals are exchanged weekly between the producers and traders for different purposes or sells in the primary markets. The current survey carried out on income generated from beef cattle production, $95 \%$ of the respondents replied that it was increasing. Market information is vital to minimize information gaps and uncertainties that exist in the agricultural sector. According to the results of this study on market information sources, the majority of the respondents, $78.8 \%$ get destination market information before they went out to sell their beef cattle. The primary marketing area was Yadota market is located $680 \mathrm{~km}$ from the capital, Addis Ababa, the capital of Saylem woreda. There are two market days, Saturday and Tuesday. Saturday, is the major market day for livestock. Regarding the marketing route, there are two main livestock-marketing routes (Jimma town and Mattu town) in the study area. From the respondents $76.2 \%$ were sold on Yadota market and 23.8\% were on Techib markets. $83.8 \%$ of the respondents sold for traders, $8.8 \%$ for abattoirs and $7.5 \%$ for local butchers. In this study, $11.2 \%$ of the respondents replied that beef cattle marketing the price was depends color, $5 \%$ on age, $2.5 \%$ on weight and $81.2 \%$ depends on color, age, weight of the animal and the negotiation between the sellers/producers and the buyers. Prices also depend mainly on supply and demand, which is heavily influenced by the season of the year and the occurrence of religious and cultural festivals. Purchasing of live cattle at the markets is performed based on the requirements of the customers. Thus breed, sex, age, weight and sometimes color of the animal for the live export are the major criteria considered by the export abattoirs during purchase. Due to lack of weighing facilities, mostly cattle transaction is done 'based on evaluation and assessing the body conditions, which tend to be highly subjective.

\subsection{Major factors affecting for beef cattle production in the study area}

Major constraints for beef cattle production are summarized in Table 5. The major constraints for the production of beef cattle in the study area assessed data showed that $68.8 \%$ had health problem of cattle, while $31.2 \%$ had a problem of shortage of feed and water and lack of genetically improved breeds of beef cattle in the area. National Bank of Ethiopia (2002) indicated that the problem of feed and water is much more pronounced during drought crises, which is a recurrent phenomenon in beef cattle producer areas. From the survey results on the prevalence of diseases problem in beef cattle indicated that $92.5 \%$. This result is in line of agreement with Daniel (2008) reported $92.6 \%$ of the respondents there is cattle health problem in the study areas. Based on animal health services, $53.8 \%$ of the respondents use veterinarians' service while $16.3 \%$ used traditional medications only; indicated that the traditional medications are relatively cheaper than the modern one. But $30 \%$ used both modern and traditional medications. The frequent occurrence of livestock diseases in the area directly inflict a heavy loss on the economy of the society and further regaining of their market takes time.

In the study area, the producers $96.2 \%$ trek their animals by foot due to absence of road access in the area. Road networks provide the necessary links and access to services and markets for agricultural commodities among others. However, results of this study revealed that producers used traditional stock routes to move their animals to the markets. The results of this study revealed that $100 \%$ of the respondents trek their cattle to primary markets. This finding is consistent with the report of Aklilu (2002) stated that in Ethiopia, the supply of livestock to the primary, secondary and terminal markets is mostly done through trekking. The larger proportions of the producers trek their own animals to markets along with relatives or neighbors, and is aimed at minimizing costs. Lack of access to transport networks limits poor communities from market participation and constrains their economic opportunities and then contributing to inability to strengthen human capabilities and this agrees with results of this study. 
Table 1. General demographic characteristic results of the households participated in interview.

\begin{tabular}{|c|c|c|c|c|}
\hline Characteristics & No. of respondents & Percent (\%) & $\mathbf{X}^{2}$ & P-value \\
\hline \multicolumn{5}{|l|}{ Kebele: } \\
\hline Dino & 20 & 25 & 4.230 & 1.00 \\
\hline Techib & 20 & 25 & & \\
\hline Senteria & 20 & 25 & & \\
\hline Qoci & 20 & 25 & & \\
\hline \multicolumn{5}{|l|}{ Gender: } \\
\hline Male & 69 & 86.2 & 3.056 & 0.978 \\
\hline Female & 11 & 13.8 & & \\
\hline \multicolumn{5}{|l|}{ Marital status: } \\
\hline Marriage & 77 & 96.2 & 4.525 & 0.064 \\
\hline Single & 2 & 2.5 & & \\
\hline Divorced & 1 & 1.2 & & \\
\hline \multicolumn{5}{|l|}{ Age: } \\
\hline Young & 14 & 17.5 & 9.825 & 0.0011 \\
\hline Adult & 45 & 56.2 & & \\
\hline Old & 21 & 26.2 & & \\
\hline \multicolumn{5}{|l|}{ Educational status: } \\
\hline Illiterates & 25 & 31.2 & 2.600 & 2.034 \\
\hline Basic writing and reading & 35 & 43.8 & & \\
\hline Primary school & 9 & 11.2 & & \\
\hline Secondary school & 11 & 13.8 & & \\
\hline \multicolumn{5}{|l|}{ Sources of income: } \\
\hline Crop production & 5 & 6.2 & 16.002 & 0.001 \\
\hline Livestock production & 5 & 6.2 & & \\
\hline Wage labor & 2 & 2.5 & & \\
\hline Both crop and livestock production & 68 & 85 & & \\
\hline
\end{tabular}

Table 2. Questionnaire results of beef cattle production system.

\begin{tabular}{|c|c|c|c|c|}
\hline Characteristics & No. of respondents & Percent (\%) & $\mathbf{X}^{2}$ & P-value \\
\hline \multicolumn{5}{|l|}{ Involved in beef cattle production: } \\
\hline Yes & 63 & 78.8 & 26.450 & 0.000 \\
\hline No & 17 & 21.2 & & \\
\hline \multicolumn{5}{|l|}{ Purpose of beef cattle rearing: } \\
\hline To generate cash income & 38 & 47.5 & 1.900 & 2.546 \\
\hline For farming & 8 & 10 & & \\
\hline Both for selling and farming & 34 & 42.5 & & \\
\hline \multicolumn{5}{|l|}{ From whom do you get support: } \\
\hline Office of agriculture & 49 & 61.2 & 6.900 & 1.873 \\
\hline Fellow farmers & 12 & 15 & & \\
\hline Administrative conferences & 7 & 8.8 & & \\
\hline From all & 12 & 15 & & \\
\hline \multicolumn{5}{|l|}{ Is the technical support is sufficient: } \\
\hline Yes & 54 & 67.5 & 19.800 & 0.020 \\
\hline No & 26 & 32.5 & & \\
\hline \multicolumn{5}{|l|}{ On what issue do you get support: } \\
\hline On health of beef cattle & 36 & 45 & 2.400 & 2.523 \\
\hline On feed and marketing of beef cattle & 10 & 13.6 & & \\
\hline On beef cattle utilization & 2 & 2.5 & & \\
\hline On all aspects motioned above & 32 & 40.1 & & \\
\hline \multicolumn{5}{|c|}{ What production system do you follow: } \\
\hline Traditional & 77 & 96.2 & 28.450 & 0.031 \\
\hline Modern & 3 & 3.8 & & \\
\hline
\end{tabular}

$\overline{\mathbf{X}^{2}}$ Pearson Chi-square 
Table 3. Questionnaire results on feeding system of beef cattle production.

\begin{tabular}{|c|c|c|c|c|}
\hline Characteristics & No. of respondents & Percent (\%) & Chi-square $\left(\mathbf{X}^{2}\right)$ & P-value \\
\hline \multicolumn{5}{|c|}{ Do you have sufficient grazing land: } \\
\hline Yes & 64 & 80 & 4.800 & 2.641 \\
\hline No & 16 & 20 & & \\
\hline \multicolumn{5}{|l|}{ Is there feed shortage: } \\
\hline Yes & 36 & 45 & 6.775 & 0.521 \\
\hline No & 27 & 33.8 & & \\
\hline It depends on season & 17 & 21.2 & & \\
\hline \multicolumn{5}{|c|}{ When is feed shortage was critical: } \\
\hline During dry season & 71 & 88.8 & 48.050 & 0.020 \\
\hline During summer season & 9 & 11.2 & & \\
\hline \multicolumn{5}{|c|}{ Do you store feed for your cattle: } \\
\hline Yes & 3 & 3.8 & 68.450 & 0.000 \\
\hline No & 77 & 96.2 & & \\
\hline \multicolumn{5}{|l|}{ Feed resource utilized: } \\
\hline Grazing of field grass & 75 & 93.8 & 61.250 & 0.002 \\
\hline Crop residue & 5 & 6.2 & & \\
\hline \multicolumn{5}{|c|}{ Source of water for your cattle: } \\
\hline Rivers & 54 & 67.5 & 10.825 & 0.744 \\
\hline Mechanically assisted & 26 & 32.5 & & \\
\hline \multicolumn{5}{|c|}{ Is there problems regarding water:: } \\
\hline Yes & 42 & 52.5 & 0.200 & 1.655 \\
\hline No & 38 & 47.5 & & \\
\hline
\end{tabular}

Table 4. Results of beef cattle marketing system of the study area.

\begin{tabular}{lllll}
\hline Variables & No. of respondents & $\begin{array}{l}\text { Percent } \\
(\boldsymbol{\%})\end{array}$ & $\begin{array}{l}\text { Chi-square } \\
\left(\mathbf{X}^{2}\right)\end{array}$ & P-value \\
\hline $\begin{array}{l}\text { Income you generating from beef cattle: } \\
\text { Increasing }\end{array}$ & 76 & 95 & 64.800 & 0.000 \\
Decreasing & 4 & 5 & & \\
Do you get market information: & & & & \\
Yes & 63 & 78.8 & 2.645 & 0.963 \\
No & 17 & 21.2 & & \\
Where do you sell your beef cattle & & & & \\
Yadota & 61 & 76.2 & 22.050 & 0.011 \\
Techib & 19 & 23.8 & & \\
To whom do you sell: & & & & \\
Traders & 67 & 83.8 & 19.525 & 0.023 \\
Abattoirs & 7 & 8.8 & & \\
Local butchers & 6 & 7.5 & & \\
What factors determined its price: & & & & \\
Color & 9 & 11.5 & 19.000 & \\
Age & 4 & 5 & & \\
Weight & 2 & 2.5 & & \\
Color, age, weight and agreement of seller and buyer & 65 & 81.2 & & \\
\hline
\end{tabular}


Table 5. Major constraints for beef cattle production.

\begin{tabular}{|c|c|c|c|c|}
\hline Variables & No. of respondents & Percent (\%) & $\mathrm{X}^{2}$ & P-value \\
\hline \multicolumn{5}{|l|}{ Major constraints for beef production: } \\
\hline Health problems & 47 & 68.2 & 35.054 & 0.042 \\
\hline Feed and water, improved breed & 33 & 31.8 & & \\
\hline \multicolumn{5}{|l|}{ Is a problem of beef cattle disease: } \\
\hline Yes & 74 & 92.5 & 54.321 & 0.003 \\
\hline No & 6 & 6.5 & & \\
\hline \multicolumn{5}{|l|}{ Whom do you assist for health service: } \\
\hline Veterinarians & 43 & 53.8 & 7.500 & 1.683 \\
\hline Traditional medications & 13 & 16.3 & & \\
\hline Both veterinarians and traditional medications & 24 & 30 & & \\
\hline \multicolumn{5}{|l|}{ Is a problem of road (transportation): } \\
\hline Yes & 77 & 96.2 & 32.200 & 0.0043 \\
\hline No & 3 & 3.8 & & \\
\hline
\end{tabular}

$\overline{\mathbf{X}^{2}=}$ Pearson Chi-square

\section{Conclusions}

In the study area farmers practiced traditional beef cattle production system. The unbalanced beef cattle marketing supply and demand of the area is due to poor veterinary service; poor market extension services; poor infrastructure development; low prices and selling options and numerous weaknesses of livestock marketing system. The major constraints for the expansion of beef cattle production in the area were lack of awareness of the farmers to use modern system of beef cattle production; lack of road access in the area; shortage of veterinary services; shortage of quality feeds and clear water; lack of genetically improved breeds of cattle; the prevalence of cattle disease and poor management system of beef cattle. Based on this study, the following points are forwarded:-

$\checkmark$ Administrative bodies concerned these issues should give priority to find solution for these problems facing beef cattle producing farmers in the study area.

$\checkmark$ Improve animal health services delivery including vaccine for major diseases and drug supply system with close monitoring and supervision.

$\checkmark$ Development of extension services in the areas in terms of beef cattle production, management and marketing systems.

\section{Acknowledgements}

The authors would like to thank Saylem Woreda Livestock and Fishery Development office management bodies for their constructive comment and to the farmers for their cooperation during data collection.

\section{Conflict of interest}

None to declare.

\section{References}

Nigusse T, 2001. The Productivity and Profitability of Wheat and Teff Technologies in Selected Villages of Ethiopia. M.Sc. thesis presented to Addis Ababa University, Addis Ababa, Ethiopia.

CSA, 2014. Livestock and livestock characteristics; Private peasant holdings; \# 364, CSA, Addis Ababa, Ethiopia.

Livestock Marketing Authority (LMA), 2001. Study on Causes of Cross-Border Illegal Trades in South, Southwest and Eastern Ethiopia, Market Research and Promotion Department, Addis Ababa, Ethiopia.

Solomon A, A Workalemahu, B Hurrisa, MA Jabbar and MM Ahmed, 2003. Livestock marketing in Ethiopia: A review of structure, performance and development initiatives. Socio-economic and Policy Research Working Paper 52. ILR (International Livestock Research Institute), Nairobi, Kenya. 35pp.

Bailey D, CB Barrett, PD Little and F Chabari, 1999. "Livestock markets and risk management among East African pastoralists: a review and research agenda". GL-CRSP PastoraRisk Management Project Technical Report No. 03/99. Utah State University.

Elias M, G Berhanu, D Hoekstra and M Jabbar, 2007. Analysis of the Ethio-Sudan cross-border cattle trade: The case of Amhara Regional State. IPMS (Improving Productivity and Market Success) of Ethiopian Farmers Project Working Paper 4. ILRI (Internationa Livestock Research Institute), Nairobi, Kenya. 41 pp. 
Daniel T, 2008. Beef Cattle Production System and Opportunities for Market Orientation Borena Zone, Southern Ethiopia. A Thesis Submitted to the Departmentof Animal Science, School of Graduate Studies. Haramaya University, Ethiopia.

Saylem Woreda Livestock and Fishery Development Office, 2018. General description of Saylem woreda agro ecology for livestock production annual report. Pp. 3-5.

National Bank of Ethiopia (NBE), 2002. Annual Report. In New Partnership for Africa's Development (NEPAD) - Comprehensive Africa Agriculture Development Programme (CAADP) Ethiopia: Investment Project Profile "Live Animal and Meat Export" - Preliminary Options Outline.

Aklilu Y, 2002. An Audit of the Livestock Marketing Status in Kenya, Ethiopia and Sudan. (Volume I). Nairobi, Kenya.

Bruk Y and Tafesse M, 2000. Pastoralism and Agro-pastoralism: past and present. In Pastoralism and Agropastoralism which way forward? Proceeding $8^{\text {th }}$ annual conference of the Ethiopian Society of Animal Production (ESAP) held in Addis Ababa, Ethiopia.

Sintayehu G, M Samuel, B Derek and S Ayele, 2010. Diagnostic study of live cattle and beef production and marketing. Constraints and opportunities for enhancing the system. 